\title{
Prediction of Financial Distress of Non-Bank Financial Institutions of Bangladesh using Altman's Z Score Model
}

\author{
Tania Hamid ${ }^{1}$, Farzana Akter ${ }^{1} \&$ Naharin Binte Rab ${ }^{1}$ \\ ${ }^{1}$ Senior Lecturer, Department of Business Administration, East West University, Bangladesh. \\ Correspondence: Tania Hamid, Department of Business Administration, East West University, Bangladesh. \\ E-mail: thd@ewubd.edu
}

Received: October 24, 2016

Accepted: November 18, 2016

Online Published: November 20, 2016

doi:10.5539/ijbm.v11n12p261

URL: http://dx.doi.org/10.5539/ijbm.v11n12p261

\begin{abstract}
The Non-Bank Financial Institutions (NBFIs) comprise a rapidly growing segment of the financial system in Bangladesh. They are gaining increased popularity in recent times. They play a vital role in the economy. This study attempts to predict the financial health of 15 publicly traded NBFIsof Bangladesh over five years ranging from 2011 to 2015 using Altman's Z Score Model (1965). The results show that most of the sampled NBFIs are in 'Distress' zone, Some of sample NBFIs are nationally and internationally acclaimed for their outstanding performances and contributions to the industrial as well as economic development of the country, but they fail to attain the minimum score. Most of the companies are lying on the bankruptcy level. Hence, the study suggests the stakeholders, including regulatory authorities and researchers to be more watchful of the operations of NBFIs.
\end{abstract}

Keywords: Altman Zscore, financial distress, non-bank financial institutions, bankruptcy

\section{Introduction}

Non-Bank Financial Institutions (NBFIs) are the financial institutions that provide financial services including banking, though they do not hold a banking license. Non-Bank Financial Institutions in Bangladesh are gaining increased popularity in recent times. The major business of NBFIs is leasing, but some of them are diversifying into other lines of businesses, like term lending, real-estate financing, merchant banking, equity financing, venture capital financing, etc.These institutions are prohibited to accept deposits from the public. The emergence of NBFIs in Bangladesh is complementary to commercial banks. Started in 1981, the size of the nonbanking financial sector has grown in both absolute and relative terms.

The NBFIs offer wide range of products and services to mitigate the financial intermediation gap and thereby, play a balancing roleside by side with commercial banksin the society (Shrestha, 2007; Sufian, 2008; Vittas, 1997). According to Ahmed and Chowdhury (2007), they explained that NBFI sector is accelerating due to some key limitations inherited in the banking sector.Hossain and Shahiduzzaman (2002) focused on the importance of non-banking sector as a medium for the economic development of the country and focuses on the prevailing problems existed within the sector.

Sufian (2007) opines that BFIs and NBFIs enhance the overall growth of the economy with the support of efficient money and capital market and NBFIs plays important role in providing financial services besides the commercial banks. Sufian (2007) also states that with the growth of NBFIs, capital market's financial stability also improves. Moreover, as the key player in the development of capital market, profit earning and competent NBFIsguide the economy to shift into market based. Ahmed and Chowdhury (2007) urge that NBFIs intensify the country's financial system, contribute to the economic development of the country through diversified financial services in the market. Many researchers have analyzed the development, growth and the changes over time of this sector as well as its impact on the economy to evaluate the structure of this industry.

In the relatively advanced economies, there are some classifications of Non-Bank Financial Institutions, namely, investment banks, finance companies, other institutions dealing with pension and mutual funds, though financial innovation and insurance companies aremaking hazy the differences among various institutions. Usually, financial institutions provide both banking and non-banking financial servicessimultaneously to meet the diversified requirements of the customers. The main functions of NBFIs are to give loans and advances for 
manufacturing and industry, business and commerce, housing and real estate, agriculture,carry on underwriting or taking over business or the investment and re-investment in share instruments, bonds, debentures or debenture stocks or securities issued by the government or any regulatory bodies; carry on the business of hire purchase transactions including leasing, and use their fund to invest in companies (Kiragu, 1993). The financial system of Bangladesh is such that NBFIs are a necessity for the sake of economy. Though commercial banks are considered the dominants players in the financial system, they have some structural limitations and rigidity of different regulations, such as not being able to expand their operations in all expected areas rather being confined to a relatively limited sphere of financial services, asset-liability mismatch to meet long term financing with short term resources, which can create pressure on their financial base (Carmichael \&Pomcerleano, 2002). To fill up that gap of escalating industrialization and economic growth the emergence of NBFI sector is required.

From the very beginning, Bank Financial Institutions (BFIs) plays very significant role in economic and development of infrastructure in Bangladesh. The history of NBFIs is a new one. But with the passage of time NBFIs have become an integral part of the financial system of Bangladesh. Mobilization of savings for investment is greatly influenced by NBFIs alongside the banking sector(Eidleman, 2007). According to Beck and Rahman (2006), there is a positive relationship between the progress of financial intermediation and economic growth. They also urged that financial intermediaries help to control the reverse causation of economic growth. Islam and Osman (2011) tried to find out that whether there is any association between per capital real GDP and the NBFIs based on Malaysian market. They reported that there is a long term as well as stable association between per capita real GDP and the NBFIs' investment, trade openness, and employment. Pirtea, Iovuand Milos (2008) expressed that with the development of NBFIs, financial system and domestic capital market also develop, that in turn contribute to the overall economic development of the country. Vittas (1997) expressed that NBFIs creates long-term financial resources and provides a strong stimulus to the development of capital market by creating new marketable securities in the area of leasing, factoring and venture capital.

As the NBFIs deal with peoples' money and some are even publicly traded, these NBFIs must be practicing faithful business practices and the managers of these NBFIs are trying to maximize the stakeholders' wealth. In light of recent events that have taken place in Bangladesh, the importance of knowing the financial health of NBFIs is imperative to stakeholders. The focus of this study is to check the financial soundness of NBFIs with the use of Altman's Z Score Bankruptcy Model. The Z score values have widely been used for prediction of bankruptcy from the beginning of the inception of the model. Our work is such an investigation that uses Altman $Z$ Scores and provides an indication to stakeholders about the financial stability of the organizations under study.

Our work seeks to provide valuable insights into the financial condition of some of the publicly traded NBFIs. On the ground of recent banking scandals and the uncertainty concerning future frauds, this study may help the stakeholders to be more careful about any such banking frauds that can take place in future.

\section{Overview of NBFI Sector in Bangladesh}

NBFI or Non-Bank Financial Institution is also known as NBFC (Non-Bank Finance Companies). In Bangladesh NBFI sector is monitored and controlled by Bangladesh Bank under the guideline of Financial Institution Act, 1993. According to Financial Institution Act 1993, NBFIs are defined as, "financial institution means such non-banking financial institutions, which- make loans and advances for industries, commerce, agriculture or building construction; or carry out the business of underwriting, receiving, investing and reinvesting shares, stocks, bonds, debentures issued by the Government or any statutory organization or stocks or securities or other marketable securities; or carry out installment transactions including the lease of machinery and equipments; or finance venture capital; and shall include merchant banks, investment companies, mutual associations, mutual companies, leasing companies or building societies". At present, there are in total 32 NBFIs with 198 branches are operating within the financial sector of Bangladesh among which three NBFIs are state owned, nineteen privately owned and ten joint venture NBFIs. At the end of June 2015, NBFI sector managed to collect total deposit of Taka 271.8 billion which were invested in different sectors like 44.9 percent in industry, 17.4 percent in real estate, 3.2 percent in margin loan, 16.0 percent in trade and commerce, 4.0 percent in merchant banking, 1.7 percent in agriculture and 12.9 percent in other sectors. Therefore, total assets of NBFI sector increased to Taka 563.8 billion. The profitability indicators, for instance ROA and ROE of this sector in June 2015 were $1.3 \%$ and $7.6 \%$ respectively(Bangladesh Bank, 2015).

\section{What Is Financial Distress?}

For corporate world, 'Distress' indicates 'Financial Distress'. In this situation a business firm is usually facing difficulties in generating sufficient cash flows from its operation, thus it would be unable to meet the current obligations as well as creditors demand. Brealeys Myers, Allen and Mohanty said "Financial distress occurs 
when promises to creditors are broken or honored with difficulty" (Brealey, Myers, \& Allen, 2006). Ross, Westen Field and Jaffe said, "Financial distress is a situation where a firm's operating cash flows are not sufficient to satisfy current obligations and the firm is forced to take corrective action (Ross, Westerfield, \& Jaffe, 2005). If any company is unable to solve the problem of financial distress immediately, it may reduce its dividends, close plants, recurring losses, layoffs, plummeting stock price and eventually it may lead to bankruptcy. Therefore it is necessary to take effective measures to get rid of this problem in exchange of some costs known as financial distress costs. A business can restructure the overall business or merge with another firm to work out the financial distress. But there is no certainty that all these protective measures will be $100 \%$ successful. Finally we can consider financial distress as an 'early warning' system for future downfalls. Firms burdened with financial leverage will experience distress more often which is unlikely to firms with lesser debt. That's why prediction of financial distress is compulsory from the very beginning of a business lifecycle.

\section{Literature Review}

The recent emergence of NBFIs as financial intermediaries is noticeable both in developed countries and in developing countries, but the research on various issues of NBFIs remains substantially scarce (Sufian, 2008); (Kogi 2003). Empirical evidence regarding the evaluation of development and growth of the non-banking sector stays even more insignificant, particularly in the context of developing countries. With regard to the literature, so far a small number of studies have been conducted, concerning the nonbanking sector in Bangladesh. That is why it is imperative to measure the financial health of NBFIs in Bangladesh to predict possible financial distress and bankruptcy.

Prediction of bankruptcy has taken an important attention for corporate governance, argued by many researchers such as Gilson (1989); Gilson (1990); DattaandIskandar-Datta(1995). In their research, Telmoudi, Ghourabi, and Limam (2011) focused on prediction of financial condition of firms by pointing out that if early warning signals can be identified with the failing firms, it can deter managers from making poor investment decisions as well as from implementing required actions that will help to offset possible future losses. It is the potential bankruptcy and the consequences associated with it that have made academic researchers from all over the world to keep developing a large number of models regarding corporate failure prediction, based on various types of modeling techniques (Aldrich \& Nelson, 2007); (Simic, Evic,\&Simic, 2012).. Ross, Westerfield, Jaffe, and Jordan (2007) defined financial distress as a situation in which a firm does not have sufficient operating cash flows to satisfy current obligations and the firm is forced to take necessary measures. In his research, O'Leary (2001) provides an argument that prediction of bankruptcy probably is one of the most important tasks relating to business decision-making problems that affect the entire life span of a business as the failure results in a high cost from the all types of stakeholders as well as from the country's economy.

Jaisheela (2015) researched on 27 Indian leasing companies by $Z$ score formula and revealed that $22 \%$ were in grey zone and $27 \%$ had very strong probability to get sick. Vaziri, Bhuyan, and Manuel (2012) analyzed on financial institutions and took 100 banks as samples which are from Europe, USA and Asia. They used several models including $\mathrm{Z}$ score to predict bankruptcy. Their results showed that all the models can forecast bankruptcy correctly before filing but z-score model could predict it more accurately than the other models.

In Bangladesh, distress analysis has been done on several industries such as; banking, capital market, insurance companies, ceramic companies (Masum\&Johora, 2015), SME (Jahur\&Quadir, 2012), pharmaceutical companies (Islam \&Mili, 2012), cement companies (Hossain\&Moudud-Ul-Huq, 2014)and some other industries but yet not done on NBFIs. Ahmed and Alam (2015) analyzed Z-score on 15 commercial banks of Bangladesh and find out that most of the banks belong to distress zone. They find out that only $7 \%$ of the sample banks were in healthy financial position in 2009 which started declining gradually and after 2011 there was none. They also revealed a transition of the banks from the distress zone to grey zone. Mostofa, Rezina, \&Hasan (2016) investigated the insolvency level and probability to be bankrupted of the banking industry in Bangladesh. They performed their research work on 25 conventional and non-conventional commercial banks and find out a promising result compare to other research works. $24 \%$ of the sample banks were in safe zone and $20 \%$ banks were in risky zone was the final findings of their research Chowdhury and Barua (2009) used Z score model to predict the bankruptcy risk of DSE (Dhaka Stock Exchange) listed Z category companies and their results indicated that 5 out of 53 companies are out of dangers and forty one companies were in distress zone due to weaker managerial capacity and poor efficiency in operational activities. They also discussed regarding the applicability of z-score model in Bangladesh. Hasan and Khanam (2013) researched on SadharonBimaCorporation of Bangladesh from 2007 to 2011 and find out that long term solvency and liquidity were not satisfactory at that time to determine distress level. They also suggested some techniques to improve the situation like; using modern techniques for asset management, modern marketing policies etc. 
The pioneer in finding the contemporary corporate failure prediction models was William H. Beaver. Beaver (1966) undertook univariate analysis and compared the financial ratios of 79 failed firms and 79 non-failing firms. He examined the predictive power of thirty accounting ratios for five consecutive years leading up to the bankruptcy of the tested firms. Beaver applied 3 criteria in selecting these ratios; widely used in past literature, good performance of ratios in past studies and the capability of ratios to be defined as "cash flow" concept, argue Siew Bee andAbdollahi (2011).

A limitation of Beaver's work is that it is based primarily on the univariate nature that only allows for one ratio used at a time. This can give inconsistent results for a firm. Also the cut-off point determined is chosen postfailure of a company which may result in inaccurate classifications. Because of these limitations, in 1968 Edward Altman advanced upon Beaver's work by incorporating four more variables into the model to give an overall more precise prediction of manufacturing corporate failure. Altman classifies the companies into two mutually exclusive groups; bankrupt and non-bankrupt (Altman, 1968). The original Altman model took the following form:

$$
Z=0.012 X 1+0.014 X 2+0.033 X 3+0.006 X 4+0.999 X 5
$$

Where:

$\mathrm{X} 1=$ Working capital/Total assets;

$\mathrm{X} 2=$ Retained earnings/ Total assets;

$\mathrm{X} 3=$ Earnings before interest and taxes/Total assets;

$\mathrm{X} 4=$ Market value of equity/Book value of Total liabilities;

$\mathrm{X} 5=$ Sales/Total assets.

A resulting low score suggests the firm is in financial distress. Companies with $\mathrm{Z}$ scores below 1.81 would be classified as potential failures; $\mathrm{Z}$ scores between 1.81 and 2.99 are said to be in the zone of ignorance or grey area and above 2.99 indicates the company is not in any financial distress. Using the above model, Altman's Z Score provided evidence to predict bankruptcy of $94 \%$ of the failed companies in his sample (Altman, 1968). One limitation that made the ' $\mathrm{Z}$ score' face criticism was that the model is industry specific, as it was formulated for operating manufacturing companies, noted by Grice and Ingram (2001).

The Z score model was being constantly updated by Altman, (1983), (2002); Altman, Hartzell, and Peck, (1995) to adapt to different parameters and the changing corporate landscape. In 1983, Altman devised the $Z$ score to be adapted for private companies 'The Z' Score'.

This model took the following form:

$$
Z=0.717 X 1+0.847 X 2+3.107 X 3+0.420 X 4+0.998 \times 5
$$

Where:

X1: Working Capital/Total Assets;

X2: Retained Earnings/Total Assets;

X3: EBIT/Total Assets;

X4: Book Value Equity/Total liabilities;

X5: Sales/Total Assets.

This was further developed and updated to create the ZScore model (Altman, 1995). This model is applied to predict corporate failures for developing countries firms, emerging market companies and for non-manufacturers. The limitation of $Z$ score being applicable for manufacturing industries only was then ruled out. This model kept the first four variables as the previous Z' Score model with the exclusion of the sales/total assets activity ratio ' $\mathrm{X} 5$ ' in the following form with different weighted coefficients:

$$
Z=6.56 X 1+3.26 X 2+6.72 X 3+1.05 X 4
$$

Where:

X1: Working Capital/Total Assets;

X2: Retained Earnings/Total Assets;

X3: EBIT/Total Assets;

X4: Book Value Equity/Total liabilities. 
Apart from Altman (1968), Sinkey's (1975), Meyer's and Pifer's (1970) studies, there was limited early literature regarding the corporate failure of banks until the emergence of the recession in the mid twenty first century. Sinkey (1975) identified problem banks by saying that the most important component of the net capital ratio (NCR) is the volume of "substandard" loans; and banks that failed in recent years almost invariably had low NCRs months before failure. Ozkan-Gunay and Ozkan (2007) analyzed 59 Turkish banks, 23 of which were failed banks and 36 were non-failed using a non-linear artificial network approach. They found that $66 \%$ of the failed banks were correctly indicated and $90 \%$ of the non-failed banks were correctly indicated. Using a hybrid artificial neural network Yim (2007) predicted firm failure of Australia's financial services sector. Yim (2007) successfully predicted $100 \%$ of failed firms a year before failing but only predicted $33.3 \%$ of failed firms two years before failure. Schaeck (2008) used a quartile regression approach to compare high-cost to low-cost bank failures.

Despite critical views and practice of other alternatives, ratio-based models have been played tremendous roles in the prediction of business failures. Particularly, applicability of Altman Z score is reflected in other research studies. According to Pustylnick (2009), Altman Z score clearly shows the financial position of the firm in terms of its robustness and solvency. Nandi and Choudhary (2011) conducted a research with six years' data of Indian Banks and used Altman Z score model to design an internal credit rating by the banks so as to predict their future defaults. Later on, a confirmative study was conducted in 2013 with Euro Banks in which Cheing (2013) selected four distressed banks and previous five years' data to confirm that Altman Z score model can predict future distress of the banks. The research findings verified the predictive ability of Altman $\mathrm{Z}$ score to the Euro banks. In 2014 a further study is made on this area by SiskosD.V. He shows that it was possible to detect frauds made by Enron in 2001, which was led into the biggest corporate bankruptcy in the US at that time by using Altman z-score and MesodBeneish model.

\section{Data \& Methodology}

To identify a trend in the Z scores of NBFIs over five years starting from 2011 to 2015 and to develop an early warning system, we selected 15 out of 23 companies (see Appendix A) listed in the Dhaka Stock Exchange (DSE) from all the ratings ranging from AAA, the highest rate to $\mathrm{CCC} 3$, the lowest rate, so that the data set has greater coverage and reliability. However, the random sampling method was followed for the selection of banks from each rating. For each company selected, all the necessary data of five years starting from 2011 to 2015 were collected from the published annual reports for calculation of the four ratios used in Altman Z Score (1995). The table 1 below presents the sample details.

Table 1. Sample details

\begin{tabular}{llllll}
\hline Sector & $\begin{array}{l}\text { No. of Companies } \\
\text { Listed with DSE }\end{array}$ & $\begin{array}{l}\text { No. of Companies } \\
\text { Taken as Samples }\end{array}$ & $\begin{array}{l}\% \text { of Companies } \\
\text { Taken as Samples }\end{array}$ & $\begin{array}{l}\text { No. of Years of } \\
\text { Sample Company }\end{array}$ & $\begin{array}{l}\text { No. of Firm Years } \\
\text { of } \\
\text { Companies }\end{array}$ \\
\hline $\begin{array}{l}\text { Financial } \\
\text { Institutions }\end{array}$ & 23 & 15 & $65.22 \%$ & 5 & 75 \\
\hline
\end{tabular}

\subsection{The Statistical Model: Altman ZScore Bankruptcy Model}

To categorize banks into 'Safe', 'Grey', and 'Distress' zone, we are going to make the data of the sampled NBFIs subject to the statistical model outlined below.

$$
Z=6.56 X_{1}+3.26 X_{2}+6.72 X_{3}+1.05 X_{4}
$$

Where:

$\mathrm{X}_{1}$ : Working Capital/Total Assets;

$\mathrm{X}_{2}$ : Retained Earnings/Total Assets;

$\mathrm{X}_{3}$ : EBIT/Total Assets;

$\mathrm{X}_{4}$ : Book Value Equity/Total liabilities;

The main reason for choosing the Zscore as a statistical model is due to its high predictive ability that it produced for banks over years. This made the model very relevant for our analysis considering it had worked correctly on Indian Banks. The weightings of the variables did not change for our study as the objective was to use the original existing model to verify its validity as a predictor for Bangladeshi NBFIs. 


\section{Findings \& Analysis}

After organizing the collected data into different variables and ratios, we determined the score of each of the sampled companies for of the sample years, using Altman Z Score Model. The details of company data are shown in the appendix table. After the analysis of the data of the sampled NBFI of different years, we find that very few companies are in 'Safe' zone, only $7 \%$ in year 2013, and $0 \%$ in rest of the sample years. Only a few companies are in 'Grey' zone, $13 \%$ in $2011,0 \%$ in 2012, and $7 \%$ in rest of the years. And maximum of the companies belong to 'Distress' zone, $87 \%$ in $2011,100 \%$ in 2012, 87\% in 2013, and 93\% in 2014 and 2015. From the results, we can say that some of the NBFIs are in 'Grey' zone, and maximum of them are in 'Distress' zone over the five years of our study, the year 2012 having the highest number of companies in the 'Distress' zone. Table 2 below shows the results summary of sampled companies on the basis of Z" score:

Table 2.Results summary

\begin{tabular}{lcccccccccc}
\hline & \multicolumn{2}{c}{$\mathbf{2 0 1 1}$} & \multicolumn{2}{c}{$\mathbf{2 0 1 2}$} & \multicolumn{2}{c}{$\mathbf{2 0 1 3}$} & \multicolumn{2}{c}{$\mathbf{2 0 1 4}$} & \multicolumn{2}{c}{$\mathbf{2 0 1 5}$} \\
\multicolumn{1}{c}{ Type of Zone } & No. & $\mathbf{\%}$ & No. & $\mathbf{\%}$ & No. & $\mathbf{\%}$ & No. & \% & No. & \% \\
\hline Safe & 0 & $0 \%$ & 0 & $0 \%$ & 1 & $7 \%$ & 0 & $0 \%$ & 0 & $0 \%$ \\
Grey & 2 & $13 \%$ & 0 & $0 \%$ & 1 & $7 \%$ & 1 & $7 \%$ & 1 & $7 \%$ \\
Distress & 13 & $87 \%$ & 15 & $100 \%$ & 13 & $87 \%$ & 14 & $93 \%$ & 14 & $93 \%$ \\
Total & 15 & $100 \%$ & 15 & $100 \%$ & 15 & $100 \%$ & 15 & $100 \%$ & 15 & $100 \%$ \\
\hline
\end{tabular}

Source: Constructed by the authors based on data from annual reports of sample companies.

Based on the above result summary, a graph was drawn for understanding the trend, if there is any, in the result of $\mathrm{Z}$ score. The graph shows that the 'Safe' companies are going to lose their status over time. During the time period of 2011-2015, the companies marked 'Safe' had a little upward trend in 2013, but in rest of the years, they again went down at $0 \%$. Few companies have 'Grey' zone. During our study period, they showed a little upward trend in 2011, but they went down at $0 \%$ in the immediately following year. However, they showed a constant trend of $7 \%$ in rest of the years. On the other hand, the companies have a positive trend with 'Distress' zone. That is, they have an upward trend of being considered in the 'Distress' area over time. Though in 2009, they had a downward trend, for the rest of the sample period, the NBFIs had an upward trend toward 'Distress' zone, with highest percentage in 2012. This suggests that most of the NBFIs are in 'Distress' zone.

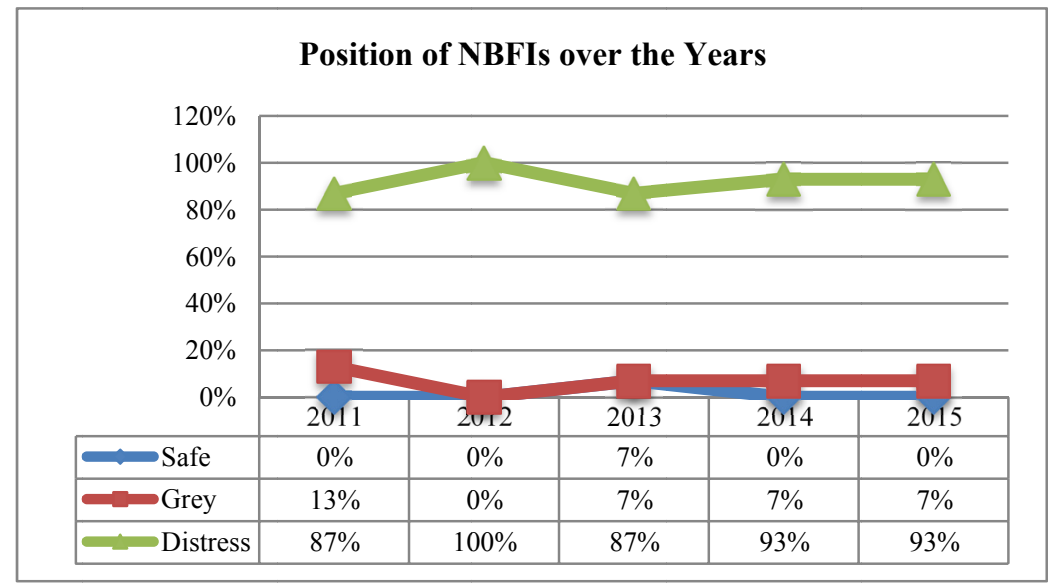

Figure 1. Trend of financial health of sampled NBFIs

The overall scenario shows that the sampled NBFIs in the sample period can be best described as being in the 'Distress' zone. Though some of them have 'Grey' trend, this trend is not upward sloping, whereas the 'Distress' trend is upward sloping. Therefore, based on our study with Z Scores, we can conclude that NBFIs have a trend of downgrading their financial health and thus tend to belong to the 'Distress' zone. The stakeholders, thus, should be watchful so as to making the companies more healthy in future years and keep improving their financial condition. 


\section{Conclusion}

From the overall discussion, findings, and analysis that tested data of fifteen non-bank financial institutions with the Altman Z score model, we can conclude that most of the banks have been in the 'Distress' zone. Though some of them are nationally and internationally acclaimed for their outstanding performances and contributions to the industrial and overall economic development of the country, they fail to attain the minimum score as per Z score model. According to the model, most of the companies are lying on the bankruptcy level. It is also to be mentioned that this model may not be appropriate for the countries like ours, but precautionary actions have to be taken to minimize future unexpected losses that might obstruct the development of the economy and industry. The findings recommend more stringent regulation by the central bank of Bangladesh and regulatory bodies for that the financial institutions play a vital role in the economy. Also this study gives guidelines for the shareholders to take future investment decision, for the regulatory authorities to implement more stringent monitoring policies, and mostly for the academicians and researchers to conduct further research in this area.

\section{References}

Ahmed, M. N., \& Chowdhury, M. I. (2007). Non-bank financial institutions in Bangladesh: An analytical review. Working Paper Series: WP 0709. Bangladesh Bank.

Ahmed, T., \& Alam, S. (2015). Prediction of financial distress in Banking companies of Bangladesh And a need for regulation by FRC. The Cost and Management, 43(6), 13-19.

Aldrich J. H., \& Nelson, F. D. (2007). Linear probability, logit and probit models. Sage Beverly Hills, Calif.

Altman, E. I. (2002). Revisiting Credit Scoring Models in a Basel 2 Environment. Salomon Center for the Study of Financial Institutions, 2(1), 2-37.

Altman, E. I. (1968). Financial Ratios, Discriminant Analysis and the Prediction of Corporate Bankruptcy. The Journal of Finance, 23(4), 589-609.

Altman, E., Hartzell, J., \& Peck, M. (1995). Emerging Markets Corporate Bonds: A Scoring System. New York: Wiley and Sons.

Altman, E. I. (1983). Corporate Financial Distress. New York: Wiley Interscience.

Bangladesh Bank. (2015). Financial Stability Report 2015.

Beaver, W. H. (1966). Financial ratios as predictors of failure. Journal of Accounting Research, 4, 71-111.

Beck, T., \& Rahman, M. H. (2006). Creating a more efficient financial system: Challenges for Bangladesh World Bank Policy Research Working Paper 3938.

Brealey, R., Myers, S., \& Allen, F. (2006). Principles of corporate finance (1st ed.). New York, NY: McGraw-Hill/Irwin.

Carmichael, J., \& Pomcerleano, M. (2002). The Development and Regulation of Non-bank Financial Institutions. Washington, D.C., USA: The World Bank.

Cheing, J. R. (2013). Verifying the Validity of Altman's Z" Score as a Predictor of Bank Failures in the Case of the Eurozone.MSc. Management, National College of Ireland.

Chowdhury, A., \&Barua, S. (2009). Rationalities of z-category shares in Dhaka stock exchange: Are they in financial distress risk?BRAC University Journal, VI(1), 45-58.

Datta, S., \& Iskandar-Datta, M. E. (1995). Corporate partial acquisitions, total firm valuation and the effect of financing method. Journal of Banking \& Finance, 19(1), 97-115.

Eidleman, E. B. (2007). A discriminant analysis of predictors of business failure. Journal of Accounting Research, 3, 167-179.

Gilson, S. C. (1989). Management Turnover and Financial Distress. Journal of Financial Economics, 25(2), 241-262.

Gilson, S. C. (1990). Bankruptcy, Boards, Banks, and Blockholders. Journal of Financial Economics, 27(2), 355-387.

Grice, J. S., \& Ingram, R. W. (2001). Test of Generalizability of Altman's Bankruptcy Prediction Model. Journal of Business Research, 10, 53-61.

Hasan, K.,\& Khanam, F. (2013).Performance Evaluation of Public Sector General Insurance Company in Bangladesh- A Case Study on SBC. European Journal of Business and Management, 5(25). 
Hossain, M., \& Shahiduzzaman, M. (2002).Development of non bank financial institutions to strengthen the financial system of Bangladesh. Journal of Bangladesh Institute of Bank Management (BANK PARIKRAMA), 28(1).

Hossain, M., \& Moudud-Ul-Huq, S. (2014).Analysis of Credit-Strength of Cement Industry in Bangladesh. MSES, 1(2), 97-114. http://dx.doi.org/10.12816/0006209

Islam, M. A., \& Osman, J. B. (2011). Development impact of non-bank financial intermediaries on economic growth in Malaysia: An empirical investigation. International Journal of Business and Social Science, 2(14), 187-198.

Islam, N., \& Mili, S. (2012). Financial Diagnosis of Selected Listed Pharmaceutical Companies in Bangladesh. European Journal of Business and Management, 4(4).

Jahur, M., \& Quadir, S. (2012). Financial Distress in Small and Medium Enterprises (SMEs) of Bangladesh: Determinants and Remedial Measures. Economia Seria Management, 15(1).

Jaisheela, B. (2015). A Study of financial health of leasing companies: Z score analysis. Journal of Business Administration and Management ScieNces Research, 4(1), 15-19.

Kiragu, M. (1993).The Prediction of Corporate Failure Using Price Adjusted Accounting Data.University of Nairobi.

Masum, A., \& Johora, F. (2015).Performance Evaluation of Selected Ceramic Companies of Bangladesh. Asian Business Review, 1(1), 37. http://dx.doi.org/10.18034/abr.v1i1.335

Meyer, P.A., \& Pifer, H.W. (1970).Prediction of Bank Failures. The Journal of Finance, 25(4), 853-868.

Mostofa, M., Rezina, S., \&Hasan, M. (2016).Predicting the Financial Distress in the Banking Industry of Bangladesh: A Case Study on Private Commercial Banks. In Dhaka International Business and Social Science Research Conference (pp. 214-227). Dhaka: Uttara University.

Nandi, J. K., \& Choudhary, N. K. (2011). Credit Risk Management of Loan Portfolios by Indian Banks: Some Empirical Evidence. The IUP Journal of Bank Management, 10(2), 7-31.

O'Leary, E. G. (2001).Business Failure Prediction and the Efficient Market Hypothesis.Simon Fraser University, November.

Ozkan-Gunay, E. N., \& Ozkan, M. (2007). Prediction of bank failures in emerging financial markets: An ANN approach, The Journal of Risk Finance, 8, 465-480.

Pirtea, M., Iovu, L. R., \& Milos, M. C. (2008). Importance of non-banking financial institutions and of the capital markets in the economy: The Case of Romania. Theoretical and Applied Economics, 5(5), 3-10.

Pustylnick, I. (2009). Combined Algorithm of Detection of Manipulation in Financial Statements. Swiss Management Center.

Ross, S. A., Westerfield, R. W., Jaffe, J., \& Jordan, B. D. (2007).Modern Financial Management(8th ed.). New York: McGraw Hill.

Schaeck, K. (2008). Bank Liability Structure, FDIC Loss, and Time to Failure: A Quantile Regression Approach. Journal of Financial Services Research, 33, 163-179.

Shrestha, M. B. (2007). Role of Non-bank Financial Intermediation: Challenges for Central Banks in the SEACEN Countries. Malaysia: The South East Asian Central Banks (SEACEN).

Siew Bee, T., \& Abdollahi, M., (2011). Corporate failure prediction: Malaysia's emerging market. The International Journal of Finance, 23(2), 6825-6851.

Simic, D., Evic, I.K, \&Simic, S. (2012).Insolvency prediction for assessing corporate financial health. Logic Journal of the IGPL, 20(3), 536-549.

Sinkey, J. F. (1975). A Multivariate Statistical Analysis of the Characteristics of Problem Banks. Journal of Finance, 30(1), 21-36.

Siskos, D.V. (2014). Detecting financial reporting fraud- Lesson learned by Enron Corp. SMC University Working Paper, 4-16.

Sufian, F. (2007). Total Factor Productivity Change in Non-Bank Financial Institutions: Evidence From Malaysia Applying A Malmquist Productivity Index (MPI). Applied Econometrics and International Development, 7(1). 
Sufian, F. (2008). The efficiency of non-bank financial intermediaries: Empirical evidence from Malaysia. The International Journal of Banking and Finance, 5(2), 149-167.

Telmoudi, F., Ghourabi, M. E., \& Limam, M. (2011).RST-GCBR-Clustering-Based RGA-SVM Model for Corporate Failure Prediction. Int. Syst. in Accounting, Finance and Management, 18(2-3), 105-120.

Vaziri, M., Bhuyan, R.,\& Manuel, P. A. V. (2012).Comparative predictability of failure of financial institutions using multiple models. Investment Management and Financial Innovations, 9(2), 120-127.

Vittas, D. (1997).The Role of Non-bank Financial Intermediaries in Egypt and other MENA Countries. World Bank Policy Research Working Paper 1892, 1-41. Washington.

Yim, J., \& Mitchell, H. (2007).Predicting Financial Distress in the Australian Financial Service Industry. Australian Economic Papers, 46(4), 375-388.

Appendix A: Details of Data of the Selected Companies

\begin{tabular}{|c|c|c|c|c|c|c|c|}
\hline Name of the Company & Year & $\begin{array}{c}\mathrm{X}_{1}=\text { Working } \\
\text { Capital/Total } \\
\text { Assets }\end{array}$ & $\begin{array}{c}\mathrm{X}_{2}=\text { Retained } \\
\text { Earnings/Total } \\
\text { Assets }\end{array}$ & $\begin{array}{c}\mathrm{X}_{3}=\mathrm{EBIT} / \text { Total } \\
\text { Assets }\end{array}$ & $\begin{array}{c}\mathrm{X}_{4}=\text { Book } \\
\text { Value } \\
\text { Equity/Total } \\
\text { liabilities }\end{array}$ & $\begin{array}{c}\mathrm{Z} \\
=6.56 \mathrm{X}_{1} \\
+ \\
3.26 \mathrm{X}_{2}+ \\
6.72 \mathrm{X}_{3}+ \\
1.05 \mathrm{X}_{4}\end{array}$ & Zone \\
\hline BD Finance and Investment Co.Ltd & 2015 & 0.00828 & 0.01015 & 0.02025 & 0.12077 & 0.35025 & Distress \\
\hline BD Finance and Investment Co.Ltd & 2014 & 0.02680 & 0.00442 & 0.01848 & 0.12509 & 0.44574 & Distress \\
\hline BD Finance and Investment Co.Ltd & 2013 & 0.03958 & 0.00654 & 0.02059 & 0.14724 & 0.57398 & Distress \\
\hline BD Finance and Investment Co.Ltd & 2012 & 0.11221 & 0.00667 & 0.01183 & 0.18402 & 1.03053 & Distress \\
\hline BD Finance and Investment Co.Ltd & 2011 & 0.00671 & 0.01572 & -0.00035 & 0.21939 & 0.32329 & Distress \\
\hline Delta Brac Housing Finance Corp. Ltd. & 2015 & -0.03536 & 0.01014 & 0.03528 & 0.09752 & 0.14056 & Distress \\
\hline Delta Brac Housing Finance Corp. Ltd. & 2014 & 0.03347 & 0.00934 & 0.03532 & 0.08906 & 0.58086 & Distress \\
\hline Delta Brac Housing Finance Corp. Ltd. & 2013 & 0.08857 & 0.00976 & 0.03057 & 0.08438 & 0.90683 & Distress \\
\hline Delta Brac Housing Finance Corp. Ltd. & 2012 & 0.01248 & 0.00980 & 0.02768 & 0.08435 & 0.38840 & Distress \\
\hline Delta Brac Housing Finance Corp. Ltd. & 2011 & -0.01690 & 0.01229 & 0.03702 & 0.07721 & 0.25905 & Distress \\
\hline Fareast Finance \& Investment Limited & 2015 & 0.15870 & 0.01222 & 0.01800 & 0.18697 & 1.39824 & Distress \\
\hline Fareast Finance \& Investment Limited & 2014 & 0.10534 & 0.01750 & 0.03552 & 0.22124 & 1.21904 & Distress \\
\hline Fareast Finance \& Investment Limited & 2013 & 0.36635 & -0.00475 & -0.00661 & 0.22405 & 2.57860 & Grey \\
\hline Fareast Finance \& Investment Limited & 2012 & 0.11207 & 0.00327 & 0.00684 & 0.26040 & 1.06519 & Distress \\
\hline Fareast Finance \& Investment Limited & 2011 & 0.24133 & 0.01658 & 0.01965 & 0.36240 & 2.14972 & Grey \\
\hline FAS Finance \& Investment Limited & 2015 & 0.01107 & 0.01086 & 0.01546 & 1.40068 & 1.68263 & Distress \\
\hline FAS Finance \& Investment Limited & 2014 & 0.03610 & 0.01976 & 0.02833 & 2.14097 & 2.73962 & Grey \\
\hline FAS Finance \& Investment Limited & 2013 & 0.04134 & 0.01775 & 0.01107 & 0.47732 & 0.90464 & Distress \\
\hline FAS Finance \& Investment Limited & 2012 & 0.06444 & 0.03009 & 0.01243 & 0.47585 & 1.10402 & Distress \\
\hline FAS Finance \& Investment Limited & 2011 & 0.13491 & 0.02856 & 0.02180 & 0.56688 & 1.71983 & Distress \\
\hline First Finance Limited & 2015 & 0.02153 & 0.00223 & 0.00334 & 0.16411 & 0.34329 & Distress \\
\hline First Finance Limited & 2014 & 0.06305 & 0.00720 & 0.01237 & 0.18061 & 0.70983 & Distress \\
\hline First Finance Limited & 2013 & 0.05070 & 0.01565 & 0.02396 & 0.24831 & 0.80539 & Distress \\
\hline First Finance Limited & 2012 & 0.09333 & 0.03206 & 0.03611 & 0.27109 & 1.24403 & Distress \\
\hline First Finance Limited & 2011 & 0.10708 & 0.03569 & 0.03600 & 0.36413 & 1.44302 & Distress \\
\hline GSP Finance Company (BD) Ltd. & 2015 & 0.06139 & 0.02927 & 0.05253 & 0.38142 & 1.25167 & Distress \\
\hline GSP Finance Company (BD) Ltd. & 2014 & 0.07550 & 0.01816 & 0.03861 & 0.41942 & 1.25430 & Distress \\
\hline GSP Finance Company (BD) Ltd. & 2013 & 0.11461 & 0.01729 & 0.03694 & 0.51181 & 1.59384 & Distress \\
\hline GSP Finance Company (BD) Ltd. & 2012 & 0.05576 & 0.02381 & 0.05184 & 0.67745 & 1.50306 & Distress \\
\hline GSP Finance Company (BD) Ltd. & 2011 & 0.04723 & 0.01717 & 0.02218 & 0.36027 & 0.89315 & Distress \\
\hline IDLC Finance Ltd. & 2015 & -0.20549 & 0.03730 & 0.03580 & 0.11860 & -0.86131 & Distress \\
\hline IDLC Finance Ltd. & 2014 & -0.23899 & 0.03790 & 0.03712 & 0.12458 & -1.06400 & Distress \\
\hline IDLC Finance Ltd. & 2013 & -0.16800 & 0.02788 & 0.02627 & 0.11898 & -0.70969 & Distress \\
\hline IDLC Finance Ltd. & 2012 & -0.16208 & 0.04640 & 0.03314 & 0.14183 & -0.54040 & Distress \\
\hline IDLC Finance Ltd. & 2011 & -0.05256 & 0.03716 & 0.03905 & 0.14641 & 0.19249 & Distress \\
\hline
\end{tabular}




\begin{tabular}{|c|c|c|c|c|c|c|c|}
\hline IPDC of BD Ltd. & 2015 & 0.08352 & 0.07132 & 0.04194 & 0.43216 & 1.51600 & Distress \\
\hline IPDC of BD Ltd. & 2014 & 0.08432 & 0.07296 & 0.04455 & 0.42040 & 1.53181 & Distress \\
\hline IPDC of BD Ltd. & 2013 & 0.07708 & 0.07592 & 0.03119 & 0.36266 & 1.34358 & Distress \\
\hline IPDC of BD Ltd. & 2012 & 0.10866 & 0.08153 & 0.01884 & 0.39847 & 1.52356 & Distress \\
\hline IPDC of BD Ltd. & 2011 & 0.10989 & 0.08460 & 0.02071 & 0.39037 & 1.54576 & Distress \\
\hline Investment Corporation of Bangladesh & 2015 & 0.10182 & 0.06525 & 0.04502 & 0.64255 & 1.85791 & Grey \\
\hline Investment Corporation of Bangladesh & 2014 & 0.08353 & 0.06826 & 0.04698 & 0.49344 & 1.60431 & Distress \\
\hline Investment Corporation of Bangladesh & 2013 & 0.68596 & 0.08699 & 0.05046 & 0.49032 & 5.63737 & Safe \\
\hline Investment Corporation of Bangladesh & 2012 & -0.02900 & 0.12494 & 0.08823 & 0.73090 & 1.57739 & Distress \\
\hline Investment Corporation of Bangladesh & 2011 & -0.03531 & 0.11618 & 0.10283 & 0.98851 & 1.87610 & Grey \\
\hline LankaBangla Finance Ltd. & 2015 & -0.02789 & 0.03413 & 0.01057 & 0.14198 & 0.14840 & Distress \\
\hline LankaBangla Finance Ltd. & 2014 & 0.10079 & 0.05081 & 0.01112 & 0.18581 & 1.09667 & Distress \\
\hline LankaBangla Finance Ltd. & 2013 & 0.13223 & 0.08880 & 0.03054 & 0.26700 & 1.64246 & Distress \\
\hline LankaBangla Finance Ltd. & 2012 & -0.00288 & 0.09614 & 0.02013 & 0.34676 & 0.79389 & Distress \\
\hline LankaBangla Finance Ltd. & 2011 & -0.29392 & 0.13400 & 0.05827 & 0.35079 & -0.73141 & Distress \\
\hline Peoples Leasing and Fin. Services Ltd. & 2015 & 0.03351 & -0.02817 & -0.02824 & 0.14752 & 0.09314 & Distress \\
\hline Peoples Leasing and Fin. Services Ltd. & 2014 & 0.00721 & 0.01277 & 0.00966 & 0.25363 & 0.42015 & Distress \\
\hline Peoples Leasing and Fin. Services Ltd. & 2013 & -0.01812 & 0.01934 & 0.01717 & 0.29950 & 0.37402 & Distress \\
\hline Peoples Leasing and Fin. Services Ltd. & 2012 & -0.10549 & 0.02722 & 0.03043 & 0.33350 & -0.04857 & Distress \\
\hline Peoples Leasing and Fin. Services Ltd. & 2011 & -0.15019 & 0.03042 & 0.04752 & 0.33259 & -0.21748 & Distress \\
\hline Premier Leasing \& Finance Limited & 2015 & 0.06056 & 0.00394 & 0.01312 & 0.08945 & 0.59220 & Distress \\
\hline Premier Leasing \& Finance Limited & 2014 & 0.00388 & 0.00179 & 0.00617 & 0.14393 & 0.22391 & Distress \\
\hline Premier Leasing \& Finance Limited & 2013 & 0.02484 & 0.00187 & 0.00980 & 0.17166 & 0.41512 & Distress \\
\hline Premier Leasing \& Finance Limited & 2012 & 0.06732 & 0.00086 & 0.00573 & 0.21680 & 0.71053 & Distress \\
\hline Premier Leasing \& Finance Limited & 2011 & 0.09332 & 0.00457 & 0.02116 & 0.23827 & 1.01942 & Distress \\
\hline Prime Finance \& Investment Ltd. & 2015 & -0.16472 & -0.00718 & -0.02119 & 0.29812 & -0.93334 & Distress \\
\hline Prime Finance \& Investment Ltd. & 2014 & 0.02015 & 0.03336 & 0.02664 & 0.40362 & 0.84374 & Distress \\
\hline Prime Finance \& Investment Ltd. & 2013 & 0.04792 & 0.03852 & 0.02705 & 0.43424 & 1.07768 & Distress \\
\hline Prime Finance \& Investment Ltd. & 2012 & 0.02697 & 0.06804 & 0.02578 & 0.46788 & 1.06323 & Distress \\
\hline Prime Finance \& Investment Ltd. & 2011 & 0.01905 & 0.10333 & 0.06311 & 0.44900 & 1.35742 & Distress \\
\hline Union Capital Limited & 2015 & 0.00740 & 0.00972 & 0.02393 & 0.14113 & 0.38925 & Distress \\
\hline Union Capital Limited & 2014 & 0.01645 & 0.00946 & 0.02449 & 0.11041 & 0.41925 & Distress \\
\hline Union Capital Limited & 2013 & 0.05839 & 0.00892 & 0.01503 & 0.16906 & 0.69064 & Distress \\
\hline Union Capital Limited & 2012 & 0.00095 & 0.00534 & 0.01039 & 0.21667 & 0.32094 & Distress \\
\hline Union Capital Limited & 2011 & 0.01031 & 0.01537 & 0.03932 & 0.23882 & 0.63276 & Distress \\
\hline United Finance Limited & 2015 & 0.00815 & 0.01223 & 0.02699 & 0.16185 & 0.44471 & Distress \\
\hline United Finance Limited & 2014 & 0.02852 & 0.01344 & 0.03395 & 0.18069 & 0.64879 & Distress \\
\hline United Finance Limited & 2013 & 0.06935 & 0.01407 & 0.03223 & 0.18404 & 0.91068 & Distress \\
\hline United Finance Limited & 2012 & 0.09242 & 0.01904 & 0.02954 & 0.19813 & 1.07486 & Distress \\
\hline United Finance Limited & 2011 & 0.13324 & 0.02494 & 0.03581 & 0.21093 & 1.41744 & Distress \\
\hline
\end{tabular}

\section{Copyrights}

Copyright for this articleis retained by the author(s), with first publication rights granted to the journal.

This is an open-access article distributed under the terms and conditions of the Creative Commons Attribution license (http://creativecommons.org/licenses/by/4.0/). 